\title{
Further Comments on the Effect of Precautionary Measures in Containing the Spread of Covid-19 [Response to Letter]
}

This article was published in the following Dove Press journal: Journal of Multidisciplinary Healthcare

\section{Arwa Alumran (D) \\ Health Information Management and Technology, College of Public Health, Imam Abdulrahman Bin Faisal University, Dammam, Saudi Arabia}

\section{Dear editor}

I would like to extend my gratitude to the editor for giving me the opportunity to respond to this interesting letter. I would also like to thank the authors for their insightful appraisal of the study at hand.

The study is attempt by the author to assess the expected number of cases in Saudi Arabia if precautionary measures were not implemented at an early stage. Therefore, the results concluded that the peak would be much higher if these measures were not implemented. Thankfully, the number of cases of Covid-19 in Saudi Arabia was contained throughout the pandemic.

The $\left(\mathrm{R}_{0}\right)$ used in the study is derived from international sources, references mentioned. The most commonly found $\left(\mathrm{R}_{0}\right)$ was the one used in this study. As for the $\mathrm{R}_{0}$ being distorted by the asymptomatic subjects, this can be cleared out since in Saudi Arabia active screening of asymptomatic cases was part of the measures used by the health authorities.

The authors of the letter mentioned that several variables may influence the case fatality rate of Covid-19. This is true and is a valid point as mentioned. ${ }^{1}$ However, measuring the variables influencing the case fatality rate from Covid-19 in Saudi Arabia is out of the scope of this specific study. ${ }^{1}$

Implementing extreme measures to combat the spread of the virus definitely have significant impact on the psychological wellbeing of the population. However, one can argue that the burden of Covid-19 disease and its consequences outweighs the psychological, moral, and financial burden of these measures.

In the study at hand, several measures were only implemented in highly infected areas, such as the capital of Saudi Arabia, Riyadh. This may have a positive influence in decreasing the economic losses effected by extreme measures implemented to the whole country.

In conclusion, perhaps other methods of containing the virus should be studied against extreme measures. The study at hand focused on assessing the effectiveness of precautionary measures implemented in Saudi Arabia on containing the spread of Covid-19, and appeared highly effective. Further studies are recommended to assess the cost-effectiveness of different interventional strategies to contain the spread of the virus. 
Finally, I would like to thank the authors again for their perceptive outlook on the study, and the editor for giving me the opportunity to respond to the letter.

\section{Disclosure}

The author declares that there is no conflicts of interest in this communication.

\section{Reference}

1. Alumran A. Role of precautionary measures in containing the natural course of novel coronavirus disease. J Multidiscip Healthc. 2020;13 (1):615-620. doi:10.2147/JMDH.S261643

Dove Medical Press encourages responsible, free and frank academic debate. The content of the Journal of Multidisciplinary Healthcare 'letters to the editor' section does not necessarily represent the views of Dove Medical Press, its officers, agents, employees, related entities or the Journal of Multidisciplinary Healthcare editors. While all reasonable steps have been taken to confirm the content of each letter, Dove Medical Press accepts no liability in respect of the content of any letter, nor is it responsible for the content and accuracy of any letter to the editor.

Journal of Multidisciplinary Healthcare

Dovepress

\section{Publish your work in this journal}

The Journal of Multidisciplinary Healthcare is an international, peerreviewed open-access journal that aims to represent and publish research in healthcare areas delivered by practitioners of different disciplines. This includes studies and reviews conducted by multidisciplinary teams as well as research which evaluates the results or conduct of such teams or healthcare processes in general. The journal covers a very wide range of areas and welcomes submissions from practitioners at all levels, from all over the world. The manuscript management system is completely online and includes a very quick and fair peer-review system. Visit http://www.dovepress.com/testimonials. php to read real quotes from published authors. 